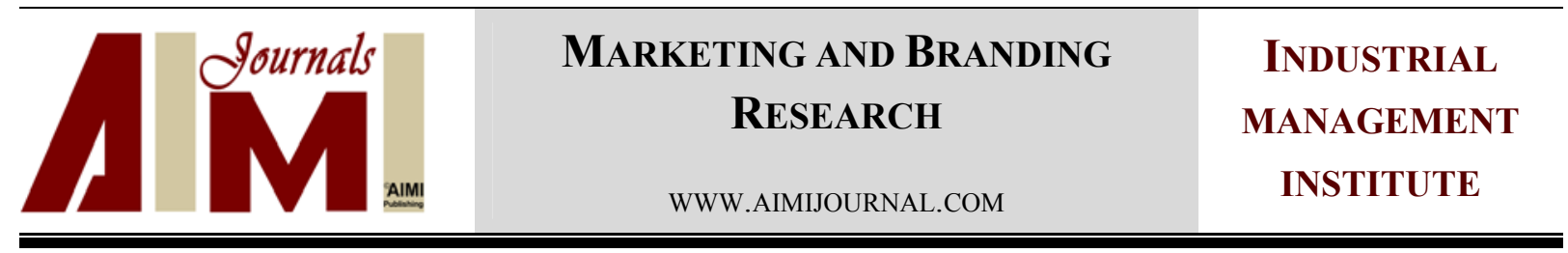

\title{
Evaluation of the Impressionability of Managerial Performance and Risk Management from Intellectual Capital Strategies in the Companies Listed on the Tehran Stock Exchange Market
}

\author{
Alireza Ahangar ${ }^{1,2}$, Farzad Sattari Ardabili1, 2* \\ ${ }^{1}$ Department of Management, Ardabil Science and Research Branch, Islamic Azad University, Ardabil, Iran \\ ${ }^{2}$ Department of Management, Ardabil Branch, Islamic Azad University, Ardabil, Iran
}

\begin{abstract}
Keywords:

Company Performance, Risk Management, Intellectual Capital, Human Capital Efficiency, Structural and Capital Efficiency

Correspondence: farzadsattary@yahoo.com

This research sought to evaluate the effectiveness of management performance and risk management from intellectual capital strategies in the companies listed in Tehran stock exchange. In this paper, management performance is measured according to Tobin model (2006) and intellectual capital according to Pulic model (2004) and risk management according to Towers Watson's model. Generally, it was conducted to investigate the significant relationships among dependent variables in the companies and suggests that the companies with higher level of intellectual capital and risk management could experience management performance with higher quality. The expectations of future investors are considered as the main factors in determining the companies' efficiency. Also, it could be concluded that human capital and structural capital have more intervention in investors' decisions. Using financial lists information of 102 companies listed on Tehran Stock Exchange Market during 1388-1392 and applying multivariable linear regression analysis, the results suggested that there is a significant and positive relationship among management performance and risk management and intellectual capital strategies.
\end{abstract}

(C)AIMI Journals

With the advent of the industrial age into the information age, the importance of Intellectual Capital (IC) has been increased. This importance can be attributed to factors such as the information technology revolution, knowledge management, knowledge-based economy, and innovation and creativity as decisive factors in the competitions. In the industrial age, the 
price of properties, machineries, available equipments, and raw materials was considered as the efficient element of each business unit while in the information age, more efficient use of IC determines the success or failure of every business. IC includes the knowledge-based portion of the total capital or assets owned by a company (Bontis, 1999).

Due to the importance of IC elements including human capital, customer capital, structural capital, and physical capital, IC has a significant impact on organizational performance. Various studies have been conducted to study the impacts of IC on organizational performance. On the other hand, today's world has left behind the past industrial economy and initiated the present knowledge-based economy. In a knowledge-based economy, knowledge production and application play significantly the most important roles in the process of wealth creation (Goh, 2005).

The concept of risk plays an important role in the financial market; thus, it is necessary to recognize and measure it in order to eliminate unnecessary risks and manage opportunitybased risks. Meanwhile, it must be noted that risk taking is not necessarily negative because risks coexists with opportunities (Chan, 2012). Accordingly, the scientific-professional field of financial engineering provides clear risk management solutions and creates opportunity. This field of study helps industry owners face with problematic situations safer and optimally invest their money (Shafizadeh, 2013).

The specific economic condition in active companies has led to the removal of tangible assets as the only sustainable competitive advantage. In fact, what is considered as a competitive advantage in the current economy is IC (Maboodi, 2010). The companies have achieved IC through effective communication with their costumers, gaining the necessary experience, reliance on their knowledge, organizational techniques, and specialized skills (King, 2012). Today, a stable profit is obtained when organizations learn how to gain and manage knowledge and convert it into IC by the help of available management processes. When companies move from an industry-based economy to a knowledge-based one, they face major challenges such as dynamics, uncertainty, and many other complexities. Obviously, in such a business environment, the need to learn more about IC and its management increases. The importance of IC has led many companies to strive to identify and manage (Donalson \& Preston, 1995; Shafizadeh, 2013). Accordingly, the present study was conducted to evaluate the impressionability of managerial performance and risk management from IC strategies in companies listed on Tehran Stock Exchange Market.

\section{Method}

The present study was a descriptive-correlational research. The study population included all companies listed on the Tehran Stock Exchange Market (TSEM) between 2009 and 2013. These companies should meet some criteria. They should have been listed on the TSEM prior to the fiscal year 2009 and have not been excluded before fiscal year 2013. Moreover, they should not have had trading interval more than three months. The companies' fiscal year should have been ended in March and have not been changed during the study period. This criterion was chosen to exclude seasonal and time-based factors. The companies should not be part of intermediary companies' investment. Investment companies adjust their earnings 
with per share of their investee companies; thus, these companies do not act in line with other companies and therefore were excluded from the study. Table 1 shows the selection of companies and sample extraction.

Table 1

The Selection of Companies and Sample Extraction

\begin{tabular}{lc}
\hline Inclusion Criteria & Number \\
\hline companies present in the stock exchange between the years 2009 and 2013 & 620 \\
manufacturing companies present in the stock exchange between the years 2009 and 2013 & 355 \\
companies that their fiscal year ended in March & 278 \\
companies that had not changed their fiscal year during the study period & 211 \\
companies that their stocks were traded at least once a year & 102 \\
companies that their data were collected & 102 \\
\hline *The final sample size was 510 companies $(102 * 5)$ &
\end{tabular}

Data were collected from the information available in the Rahavard Novin software and then were extracted based on companies' financial statements and trade statistics of the exchange organization. Equation 1 was used to measure the companies' performance (Tobin's Model, 2006). In equation 1, Q stands for Tobin's Q ratio which is an index to measure the performance of the company, ERM represents Enterprise Risk Management index, LEVERAGE indicates debt ratio obtained from the ratio of total debt to total assets, SALEGROWTH shows sale growth, ROA stands for return on assets obtained from the ratio of net income to total assets, DIVIDENDS for dividend per share, and $\varepsilon_{i t}$ for the error of measurement.

1)

$$
\begin{aligned}
& Q_{i t}=a+B_{1} E R M+B_{2} \text { SIZE }+B_{3} \text { LEVERAGE }+B_{4} \text { SALEAGROWTH }+B_{5} R O A+B_{6} \text { DIVIDENDS } \\
& +B_{7} B E T A+\varepsilon_{i t}
\end{aligned}
$$

Equation 2 is used to measure the companies' risk management, is called Watson Mode.

2)

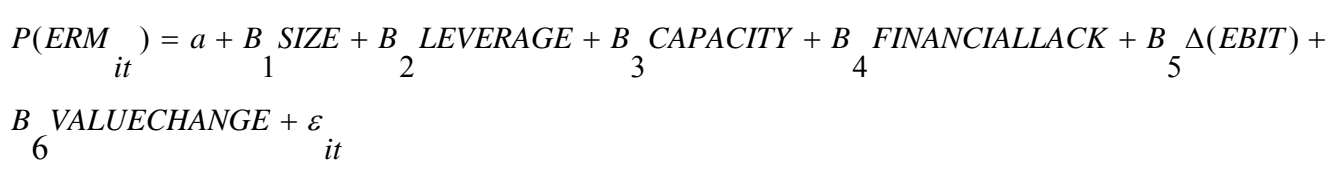

In this equation, OPACITY shows the ratio of intangible assets for carrying amount of assets while FINANCIALSLACK refers to the short-term investments and liquidity plus total assets. VALUECHANGE and EBIT refer to the changes in company's value and the earnings before interest and taxes. To measure the companies' IC, Pulic model, the equation 3 is presented. In this equation, VAIC, HCE, SCE, CEE stand respectively for value-added of IC, human capital efficiency, structural capital efficiency, physical capital efficiency. The other components such as SCE, CEE, HCE, VA, HC in equation 3 refers to SC/CE, VA/CE, $\mathrm{VA} / \mathrm{HC}$, value-added or $\mathrm{NI}+\mathrm{T}+\mathrm{DP}+\mathrm{I}+\mathrm{W}$. Other elements such as $\mathrm{HC}, \mathrm{SC}, \mathrm{CE}, \mathrm{NI}, \mathrm{T}, \mathrm{DP}, \mathrm{I}$, $\mathrm{W}$ indicate total payroll costs, structural capital, tangible assets, net income, taxes, depreciation, interests, and wages, respectively.

\section{(3) $\mathrm{VAIC}=\mathrm{HCE}+\mathrm{SCE}+\mathrm{CEE}$}


To evaluate managerial performance, equation 4 is used (James Model, 2006).

$$
\text { (4) } P E R=\frac{M E}{E-L}
$$

In equation 4, PER, ME, E, and L refer to managerial performance, market value, book value of stakeholders' wages, and book value of debt. In this study, the collected data were classified and analyzed using Excel. To analyze the statistical data, Pearson Correlation, Regression Analysis, and ANOVA were used.

\section{Results}

One-sample Kolmogorov-Smirnov test was conducted to assess whether data had normal distribution. Considering the obtained conversion formula and inserting the data value instead of the $\mathrm{X}$ variable, Table 2 shows the results of the K-S test which indicates that the scores were normally distributed (Sig. $\leq 0.05)$. Therefore, the hypothesis is rejected which indicates a lack of normality in the remaining research models. Given that the distributions of variables are affected by the distributions of remaining, the dependent variable's data in this study must have been normally distributed to increase the reliability of the following tests which is done based on Johnson Model in Figure 1. In Johnson Model, some calculations are performed on the data for normalization and then the user will be provided by a conversion formula as the model's output.

Table 2

Kolmogorov-Smirnov Test Results

\begin{tabular}{|c|c|c|c|c|}
\hline \multicolumn{2}{|c|}{ Number } & \multirow{2}{*}{$\begin{array}{c}\begin{array}{c}\text { Company } \\
\text { Performance }\end{array} \\
510\end{array}$} & \multirow{2}{*}{$\begin{array}{c}\text { Risk Management } \\
510\end{array}$} & \multirow{2}{*}{$\frac{\mathrm{IC}}{510}$} \\
\hline & & & & \\
\hline \multirow[t]{2}{*}{ Normal Parameters ${ }^{\mathrm{a}, \mathrm{b}}$} & Mean & -0.24 & 0.70 & 0.02 \\
\hline & $\mathrm{SD}$ & 0.54 & 0.43 & 0.94 \\
\hline \multirow[t]{3}{*}{ Most Extreme Differences } & Absolute & 0.05 & 0.18 & 0.02 \\
\hline & Positive & 0.03 & 0.18 & 0.02 \\
\hline & Negative & -0.05 & -0.11 & -0.02 \\
\hline Kolmogorov-Smirnov Z & & 0.71 & 4.26 & 0.56 \\
\hline Asymp. Sig. (2-tailed) & & 0.72 & 0.90 & 0.75 \\
\hline
\end{tabular}

*a. Data distribution is normal

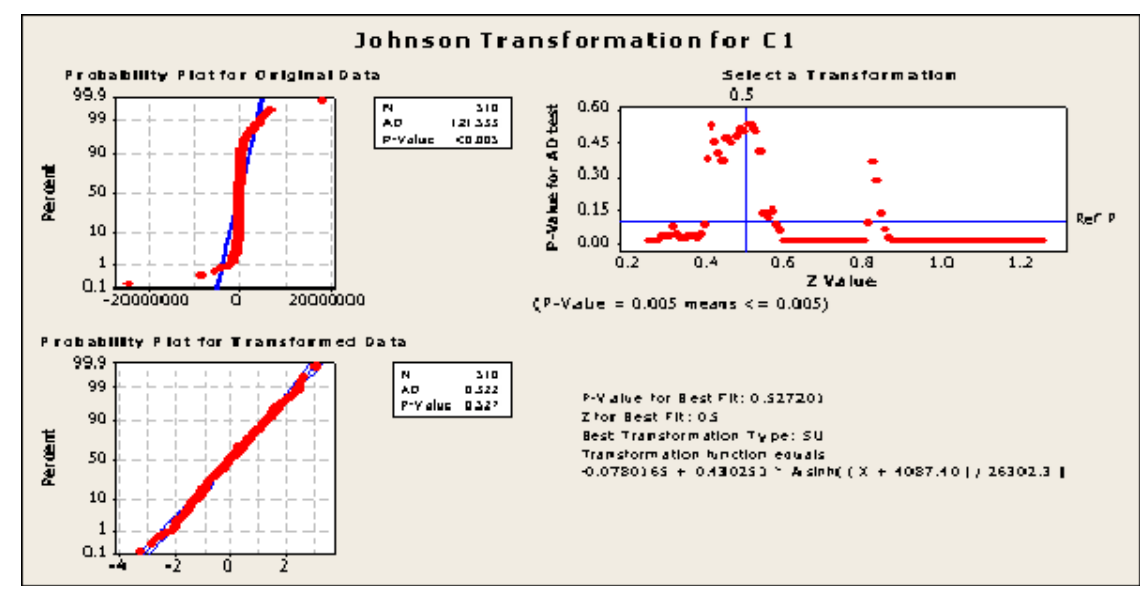


Figure1. The normal distribution based on Johnson's model

Table 3 shows the characteristics of research variables including measures of central tendency and distribution indices.

Table 3

Research Variables and their Measures of Central Tendency \& Distribution Indices

\begin{tabular}{llllll}
\hline Research Variables & Min. & Max. & Mean & SD & Variance \\
\hline Company's Performance & -89842.00 & 0.00 & 48546.19 & 15670.66 & 2456.12 \\
Risk Management & -884.00 & 1810.00 & 4847.12 & 1.5669 .66 & 2455.12 \\
Company's Size & 456.00 & 801.00 & 59770.20 & 62692.45 & 39303.43 \\
Debt Ratio & 9.00 & 188.00 & 6689.41 & 2593.48 & 672.39 \\
Sales Growth & -100.00 & 17213.00 & 9293.33 & 8122.77 & 6598.25 \\
Financial Leverage & 0.00 & 547.00 & 7865.29 & 69965.41 & 4895.15 \\
Dividend & 4003.00 & 6957.00 & 640.03 & 1197.09 & 14330.23 \\
Risk Coefficient & -18115.00 & 7177.00 & 22.02 & 1071.99 & 11491.37 \\
Intellectual Capital & -45.00 & 551.00 & 37.15 & 575.74 & 3314.79 \\
Efficiency of Human Capital & -23.00 & 257.00 & 18.16 & 2873.28 & 825.57 \\
Efficiency of Structural Capital & -670.00 & 1203.00 & 107.09 & 689.34 & 4751.95 \\
Efficiency of Physical Capital & -2277.00 & 27525.00 & 1794.54 & 2884.40 & 8319774.36 \\
Managerial Performance & -20136.00 & 7796.00 & 205.64 & 1139.10 & 12975.33 \\
Intangible Assets Ratio & 0.00 & 0.96 & 536.05 & 1014.22 & 10286.62 \\
Current Assets Ratio & 1.00 & 584.00 & 61.38 & 764.76 & 583.13 \\
Liquidity & 147.00 & 43626.50 & 119432.03 & 4.3624 .25 & 190.31 \\
Investment & 0.00 & 27774.77 & 57351.64 & 2164.15 & 468.41 \\
Company's Value & 1000.00 & 2960.55 & 1540.14 & 13819.74 & 191.08 \\
Earnings before Interest and Tax & -994.98 & 181012.27 & 446171.66 & 1495.36 & 2237.12 \\
Value-Added & 7169.97 & 131378.32 & 457804.16 & 1211.76 & 1468.12 \\
Wages & 917.41 & 18058.06 & 32084.12 & 98227.54 & 964.99 \\
Structural Capital & -8931.20 & 128297.07 & 428210.67 & 11450.96 & 1332.12 \\
Intangible Assets & 0.00 & 214615.11 & 802420.88 & 2682.56 & 7196.12 \\
\hline
\end{tabular}

Person's correlation coefficient was used for identifying the relationship between variables and investigating the possibility of each hypothesis. Table 4 reflects the results of Person's correlation for the variables of managerial performance, risk management, and IC. Correlation is significance at the 0.01 level (2-tailed) with 99 per cent confidence level. The results of Table 4 shows that there is a positive relationship between managerial performance and risk management ( $\left.\mathrm{r}: 0.87^{* *}\right)$ and moreover there is a positive relationship between managerial performance and IC (r: $0.52 * *)$.

Table 4

Correlation Test Results \& Summary of the Analysis of Hypotheses

\begin{tabular}{lccc}
\hline & 1 & 2 & 3 \\
\hline 1) Managerial Performance (Q) & -- & & \\
2) ERM (Enterprise Risk Management) & $0.87^{* *}$ & - & -- \\
3) VAIC (Value-Added Intellectual Capital) & $0.52^{* *}$ & $0.41^{* *}$ & -- \\
\hline **Correlation is significant at the 0.01 level (2-tailed). &
\end{tabular}

Table 5 
Watson Camera Test Results

\begin{tabular}{cccccc}
\hline Model & Correlation & $\mathrm{R}^{2}$ & Adjusted Coefficient of Determination & Estimated Standard Error & Watson Camera \\
\hline 1 & $0.69^{\mathrm{a}}$ & 0.58 & 0.56 & 1171.07 & 1.69 \\
\hline a. & Predictors: (Constant), VAIC, ERM & & & \\
b. & Dependent Variable (Q) & & & & \\
& & & &
\end{tabular}

One of the linear regression assumptions in this study was independence of errors; thus, if errors were not independent, there would be no possibility of regression analysis. Watson camera test is used to evaluate the independence of errors and the normality of errors (Table 5). The values in the range of 1.5-2.5 indicate the independency of errors. Accordingly, the obtained Watson value (1.69) shows the independence of errors. The overall significance of the regression was tested by the one-way analysis of variance (ANOVA). The results of ANOVA test between the variables of managerial performance, risk management, and IC are presented in Table 6. Since the indicated significance level ( $p$-value) was less than 0.05 , the assumption regarding the existence of a linear relationship between the two variables was confirmed.

Table 6

Analysis of Variance (ANOVA)

\begin{tabular}{llccccc}
\hline & Model & Total Squared & Degree of Freedom & Mean Squared & F-Value & Significance \\
\hline \multicolumn{1}{c}{1} & Regression & 1.25 & 2 & 6.24 & 4.55 & $0.00^{\mathrm{a}}$ \\
& Remaining & 6.93 & 507 & 13714.50 & & \\
& Total & 1.25 & 509 & & & \\
\hline & c. & Predictors: (Constant), VAIC, ERM & & & \\
d. & Dependent Variable: Q
\end{tabular}

Table 7 indicates the results of regression coefficient analysis. According to Table 7, there are significant relationships between the independent and dependent variables. Considering $\alpha$ and $\beta$ as constant values and regression slope for these two values, the test results for equality of the regression coefficient and constant value were less than 5 per cent. Therefore, the assumption of equality of coefficients with zero was rejected indicating that they could not be eliminated from the regression equation.

Table 7

The Results of Regression Coefficient Analysis

\begin{tabular}{|c|c|c|c|c|c|}
\hline \multirow[t]{2}{*}{ Model } & \multicolumn{2}{|c|}{ Non-Standardized Coefficients } & \multirow{2}{*}{$\begin{array}{c}\text { Standardized Error } \\
\text { Beta }\end{array}$} & \multirow[t]{2}{*}{ T-Value } & \multirow[t]{2}{*}{ Sig. } \\
\hline & $\beta$ & Std. Error & & & \\
\hline Constant Value & 455.74 & 62.95 & & 7.23 & 0.00 \\
\hline ERM & 1.21 & 1.05 & 0.87 & 29953.41 & 0.00 \\
\hline VAIC & 6.11 & 0.90 & 0.52 & 6.72 & 0.00 \\
\hline
\end{tabular}

Constant value and coefficients of independent variables are presented in Table 7; thus, the equation 5 is as follows:

$$
\text { (5) } \mathrm{Y}_{\mathrm{it}}=544.746+1.214 \mathrm{ERM}_{\mathrm{it}}+6.118 \mathrm{VAIC}_{\mathrm{it}}+\mathrm{e}_{\mathrm{i}}
$$

The correlation coefficient, adjusted coefficient of determination, and the results of Watson camera tests between the variables of managerial performance, risk management, and efficiency of physical capital are presented in Table 8. 


\begin{tabular}{cccccc}
\hline Model & Correiation & $\mathrm{R}^{2}$ & Adjusted Coefficient of Determination & Estimated Standard Error & Watsoni Camera \\
\hline 1 & $0.54^{\mathrm{a}}$ & 0.45 & 0.44 & 1.55 & 1.91 \\
\hline f. & Predictors: (Constant), CEE, ERM & & & \\
g. & Dependent Variable: Q & & & &
\end{tabular}

The obtained Watson value (1.919) presents the independence of errors; thus, conducting the regression analysis was acceptable.

Table 9

Analysis of Variance (ANOVA)

\begin{tabular}{ccccccc}
\hline & Model & Total Squared & Df & $\mathrm{R}^{2}$ & F-Value & Sig. \\
\hline \multirow{4}{*}{1} & Regression & 1.92 & 2 & 1.92 & 7.93 & $0.00^{\mathrm{a}}$ \\
& Remaining & 1.23 & 507 & 2.42 & & \\
& Total & 509 & 509 & & & \\
\hline
\end{tabular}

h. Predictors: (Constant), CEE, ERM

i. $\quad$ Dependent Variable: Q

Variance analysis between the variables of managerial performance, risk management, and efficiency of physical capital (CEE) is presented in Table 9. Hence, the overall significance of the regression model was tested by the ANOVA. Since, the indicated significance level was less than 0.05 ; the assumption regarding the existence of a linear relationship between the two variables was confirmed. According Table 10, there is a significant relationship between independent and dependent variables.

Table 10

Regression Equation's Coefficients

\begin{tabular}{cccccc}
\hline \multirow{2}{*}{ Model } & \multicolumn{2}{c}{ Non-Standardized Coefficients } & Standardized Error & \multirow{2}{*}{ T-Value } & \multirow{2}{*}{ Sig. } \\
\cline { 2 - 3 } & $\mathrm{B}$ & Std. Error & Beta & & \\
\hline Constant Value & 3647.77 & 81194.98 & & 4.49 & 0.00 \\
ERM & 1.80 & 0.78 & 0.87 & 293.37 & 0.00 \\
CEE & 67.38 & 23.91 & 0.22 & 67.38 & 0.00 \\
\hline j. $\quad$ Dependent Variable $: \mathrm{Q}$ & & & &
\end{tabular}

Table 10 includes coefficients in column B, $t$-value, and significance level which were used to test the hypothesis regarding the equality of each coefficient in column B with zero. Since, test result for equality of regression coefficient and constant value was less than 0.05 ; the assumption regarding equality of those coefficients with zero was rejected indicating that they could not be eliminated from the regression equation. Thus, the equation 6 was as follows:

$$
\text { (6) } \mathrm{Y}_{\text {it }}=3647.777+1.809 \mathrm{ERM}_{\mathrm{it}}+67.387 \mathrm{CEE}_{\mathrm{it}}+\mathrm{e}_{\mathrm{i}}
$$

The correlation coefficient, adjusted coefficient of determination, and the results of Watson camera tests between the variables of managerial performance, risk management and efficiency of structural capital are presented in Table 11.

Table 11

Watson Camera Test Results

\begin{tabular}{cccccc}
\hline Model & Correlation & $\mathrm{R}^{2}$ & Adjusted Coefficient of Determination & Estimated Standard Error & Watson Camera \\
\hline 1 & $0.58^{\mathrm{a}}$ & 0.48 & 0.47 & 1.56 & 1.92 \\
\hline a. Predictors: (Constant), SCE, ERM & & & &
\end{tabular}


b. Dependent Variable: Q

The obtained Watson value (1.92) indicates the independence of errors; thus, conducting the regression analysis was acceptable. Variance analysis between the variables of managerial performance, risk management, and efficiency of structural capital (SCE) is presented in Table 12. Hence, the overall significance of the regression model was tested by the ANOVA. Due to the indicated significance level which was less than 0.05 , the assumption regarding the existence of a linear relationship between two variables was confirmed.

Table 12

Analysis of Variance (ANOVA)

\begin{tabular}{ccccccc}
\hline & Model & Total Squared & Df & Mean Squared & F-Value & Sig. \\
\hline \multirow{4}{*}{1} & Regression & 1.25 & 2 & 6.25 & 4.191 & $0.00^{\mathrm{a}}$ \\
& Remaining & 7.56 & 507 & 1491074.10 & & \\
& Total & 1.25 & 509 & & & \\
\hline
\end{tabular}

a. Predictors: (Constant), SCE, ERM

b. Dependent Variable: Q

According to Table 13, there is a significant relationship between independent and dependent variables. Considering the amount of $\alpha$ and $\beta$ as constant value and regression slope and equality of regression coefficient and constant value which were less than 0.05 , the assumption regarding the equality of coefficients with zero was rejected.

Table 13

Regression Equation's Coefficients

\begin{tabular}{ccccccc}
\hline \multirow{2}{*}{ Model } & \multicolumn{2}{c}{ Non-Standardized Coefficients } & Standardized Error & \multirow{2}{*}{ T-Value } & Sig. \\
\cline { 2 - 4 } & $\mathrm{B}$ & Std.Error & Beta & & & \\
\hline Constant Value & 647.07 & 101.42 & & 6.38 & 0.00 \\
ERM & 0.20 & 0.78 & 0.87 & 4.25 & 0.00 \\
SCE & 99.39 & 1008.58 & 0.30 & 1.09 & 0.00 \\
\hline
\end{tabular}

Dependent Variable: Q

Thus, the equation 7 was as follows:

$$
\text { (7) } \mathrm{Y}_{\mathrm{it}}=647.071+0204 \mathrm{ERM}_{\mathrm{it}}+99.392 \mathrm{SCE}_{\mathrm{it}}+\mathrm{e}_{\mathrm{i}}
$$

The correlation coefficient, adjusted coefficient of determination, and the results of Watson camera tests between the variables of managerial performance, risk management and efficiency of human capital are estimated and presented in Table 14. The obtained Watson value (1.92) shows the independence of errors; thus, conducting regression analysis was acceptable.

Table 14

Watson Camera Test Results

\begin{tabular}{cccccc}
\hline Model & Correlation & $\mathrm{R}^{2}$ & Adjusted Coefficient of Determination & Estimated Standard Error & Watson Camera \\
\hline 1 & $0.62^{\mathrm{a}}$ & 0.58 & 0.57 & 1.55 & 1.92 \\
\hline
\end{tabular}


The analysis of variance between the variables of managerial performance, risk management, and efficiency of human capital (SCE) is presented in Table 15. The results of ANOVA revealed that the assumption regarding the existence of a linear relationship between the two variables was confirmed when the indicated significance level was less than 0.05 .

Table 15

Analysis of Variance (ANOVA)

\begin{tabular}{ccccccc}
\hline & Model & Total Squared & Df & Mean Squared & F-Value & Sig. \\
\hline \multirow{4}{*}{1} & Regression & 1.93 & 2 & 1.93 & 7.95 & $0.00^{\mathrm{a}}$ \\
& Remaining & 1.23 & 507 & 2.42 & & \\
\\
\cline { 3 - 7 }
\end{tabular}

a. Predictors: (Constant), HCR, REM

b. Dependent Variable: Q

According to Table 16, there is a significant relationship between independent and dependent variables.

Table 16

Regression Equation's Coefficients

\begin{tabular}{cccccc}
\hline Model & \multicolumn{2}{c}{ Non-Standardized Coefficients } & Standardized Error & \multirow{2}{*}{ T-Value } & \multirow{2}{*}{ Sig. } \\
\cline { 2 - 3 } & $\mathrm{B}$ & Std. Error & Beta & & \\
\hline Constant Value & 461.17 & 62.62 & & 7.36 & 0.00 \\
ERM & 12.21 & 1.82 & 0.87 & 6.70 & 0.00 \\
HCE & 6785.03 & 2405.59 & 0.40 & 2.82 & 0.00 \\
\hline a. Dependent Variable: Q & & & &
\end{tabular}

The amount of $\alpha$ and $\beta$ which stands for constant value and regression slope respectively shows that when the test results for equality of regression coefficient and constant value were less than 0.05 , the assumption regarding equality of those coefficients with zero was rejected indicating that they could not be eliminated from the regression equation. Thus, the equation 8 was as follows:

(8) $\mathrm{Y}_{\mathrm{it}}=461.176+12.214 \mathrm{ERM}_{\mathrm{it}}+6785.038 \mathrm{HCE}_{\mathrm{it}}+\mathrm{e}_{\mathrm{i}}$

\section{Conclusion}

Regarding the relationships between the mentioned independent and dependent variables in the accepted companies listed on the Tehran Exchange Stock market in the period 20092013, the results indicated that the higher levels of IC and risk management lead to a better managerial performance and that the expectations of future investors can be a major factor in determining the performance of a company. It was also found that physical, human, and structural capitals have a proper proportion with higher levels of confidence for the variable of managerial performance. It was concluded that human and structural capitals are directly involved in investors' decisions. It must be noted that compared to the developed countries, the value of local markets has been increased more with the increases in physical capital than the IC in developing countries. Therefore, the local markets are less dependent on IC as a strategic tool. One of the reasons behind this is that these markets are still dependent on sale 
and processing of physical resources as basic growth strategies. The Tehran Stock Exchange Market is not an exception; thus, structural capital and human capital, as components of IC, had the highest coefficients in this study. The overall results of this study were consistent with the results of other similar studies conducted by Zahedi and Lotfizadeh (2007), Clarke, Seng, and Whiting (2011) and Donaldson and Preston (1995). This study provided some useful recommendations for further studies. Using this model prepares, presents, and analyzes the financial statements in accounting systems to make future investment decisions based on other companies' shares. Furthermore, shareholders or investors are recommended to apply this measurement model in order to assess appropriately the true value of their organization based on IC and achieve higher financial returns in their future.

\section{References}

Bontis, N. (1999). Managing organizational knowledge by diagnosing intellectual capital: Framing and advancing the state of the field. International Journal of Technology Managing, 18(5-8), 433-462.

Clarke, M., Seng, D., \& Whiting, R. H. (2011). Intellectual capital and firm performance in Australia. Journal of Intellectual Capital, 14(12), 505-530.

Donalson, T., \& Preston, L. E. (1995). The stakeholders theory of the corporation: Concepts, evidence, and implications. Academy of Management Review, 20(1), 65-91.

Goh, P. K. (2013). Intellectual capital performance of commercial banks in Malaysia. Journal of Intellectual Capital, 6(3), 385-396.

Chan, H. K. (2012). Impact of intellectual capital on organizational performance: An empirical study of companies in the Hang Seng Index. The Learning Organization, 16(1), 4-21.

Maboodi, S. (2010). Analysis of the relationships between concentration of ownership, company's performance, and dividend policy in companies listed on the food and pharmaceutical industries of Tehran Stock Exchange (Unpublished master's thesis). Islamic Azad University, Arak.

Pulic, A. (2004). Intellectual capital: Does it create or destroy value? Measuring Business Excellence, 8(1), 62-68.

Shafizadeh, S. (2013). Analysis of the relationship between intellectual capital and financial performance in companies active in Iran capital market (Unpublished master's thesis). Islamic Azad University, Arak.

Zahedi, M., \& Lotfizadeh, F. (2007). Dimensions and models to measure intellectual capital. Journal of Management Studies, 15(55), 39-64. 